\title{
The eventful genesis of educational media
}

\author{
Citation for published version (APA):
}

Westera, W. (2012). The eventful genesis of educational media. Education and Information Technologies, 17(3), 345-360. https://doi.org/10.1007/s10639-011-9162-z

\section{DOI:}

10.1007/s10639-011-9162-z

Document status and date:

Published: 01/09/2012

Document Version:

Peer reviewed version

Please check the document version of this publication:

- A submitted manuscript is the version of the article upon submission and before peer-review. There can be important differences between the submitted version and the official published version of record. People interested in the research are advised to contact the author for the final version of the publication, or visit the DOI to the publisher's website.

- The final author version and the galley proof are versions of the publication after peer review.

- The final published version features the final layout of the paper including the volume, issue and page numbers.

Link to publication

\section{General rights}

Copyright and moral rights for the publications made accessible in the public portal are retained by the authors and/or other copyright owners and it is a condition of accessing publications that users recognise and abide by the legal requirements associated with these rights.

- Users may download and print one copy of any publication from the public portal for the purpose of private study or research.

- You may not further distribute the material or use it for any profit-making activity or commercial gain

- You may freely distribute the URL identifying the publication in the public portal.

If the publication is distributed under the terms of Article $25 f a$ of the Dutch Copyright Act, indicated by the "Taverne" license above, please follow below link for the End User Agreement:

https://www.ou.nl/taverne-agreement

Take down policy

If you believe that this document breaches copyright please contact us at:

pure-support@ou.nl

providing details and we will investigate your claim.

Downloaded from https://research.ou.nl/ on date: 26 Apr. 2023 


\title{
The eventful genesis of educational media
}

\author{
Wim Westera
}

CELSTEC - Centre for Learning Sciences and Technologies

Open University of the Netherlands

Valkenburgerweg 177

NL-PO Box 2960

6401 DL Heerlen

The Netherlands

Telephone: +31-45-5762408

Wim.westera@ou.nl

celstec.org

\begin{abstract}
This paper is a reflection on the history and future of educational media. Over the last century various new media technologies were introduced in education. Most of these failed to meet the high expectations. The paper reviews the rise and fall of various "revolutionary" learning media and analyses what went wrong. Three main driving factors are identified that influence the educational system: 1) educational practice, 2) educational research, and 3) educational technologies. The role and position of these factors is elaborated and critically reviewed. The paper concludes with identifying a number of relevant developments that substantiate a favourable future outlook of media for learning.
\end{abstract}

\section{Keywords}

Technology, learning, education, innovation, research, computer, media, history

\section{Introduction}

\begin{abstract}
About a century ago electronic media like film and radio started entering the classrooms. These early developments marked the start of systematic efforts of applying new technologies for learning and teaching. In the course of time many new technologies were introduced in education because of their anticipated positive impact on education. From the 1960s instructional television, tools for programmed instruction, audio cassettes and video cassettes became available. These developments gave rise to the new academic discipline of instructional technology: cognitive psychology-based research on effective instructional methods. After the advent of the microcomputer in the 1980s computer-assisted learning became a well-established branch of socalled educational technology, which became the new, all-embracing label for the study of learning and teaching, extending instructional design methods with the supportive technologies as well as organisational and managerial issues. The emergence of the internet in the mid 90's effected new avenues for the distribution of learning content across institutional borders. The so-called e-learning paradigm was revolutionary in that it
\end{abstract}


greatly helped enhancing the flexibility of learning with respect to the time, pace and place of learning. For expressing the innovative power of e-learning a new label was introduced that replaced the term educational technology: technology-enhanced learning. Fostered by the ever-increasing flow of new digital media services and devices that pervade our daily lives technology-enhanced learning reflects a new branch of research that includes all types socio-technical innovations for learning practices, regarding individuals and organizations (cf. Wikipedia).

This paper is a reflection on the history and future of educational media. First, major educational technologies of the last century will be briefly highlighted and reviewed for their impact on the educational system. Next, the main driving factors that influence the educational system will be analysed: 1) educational practice, 2) educational research, and 3) educational technologies. Finally, a number of issues that substantiate a favourable future outlook of technology-enhanced learning will be identified.

\section{Review of proclaimed revolutionary educational media}

This section briefly explains and evaluates a number of major 20-th century's educational media. Many of these were announced with great fanfare as the ultimate breakthrough that would procure a fundamental change of the educational system. But to a large extent they all failed to live up to their promises.

\section{Instructional film}

By the end of the 19th century Thomas Alva Edison was the first to create the technology for recording and displaying (silent) moving images. His kinetograph patented in 1892 was a new type of camera that used film rolls rather than single plates for recording (Baldwin, 1995). This invention marked the beginning of motion picture. Edison claimed that film would revolutionise education by enabling a new modality of learning content, bringing recorded realities into the classroom. It was supposed to eventually make books irrelevant, because learners would no longer need to read texts about how things work in practice, but instead they could just watch the recordings. Like Edison many innovators had high expectations.

But history took a different turn. First there were some technical practicalities linked with the size and reliability of projectors: the standard film size of $35 \mathrm{~mm}$ required bulky, noisy and expensive equipment, that displayed frequent failures. Secondly, the early celluloid strips were composed of cellulose nitrate, which could easily break and was highly flammable. Third, the amount of available instructional films was quite limited and the licenses were expensive. Two additional circumstances created problems at the adoption of film by teachers. The swift successes of the motion picture as an entertainment medium made it suspect for teachers to use it as an instructional means. A next problem arose when the sound-film was gradually replacing the silent movie. Now teachers started to oppose against films in their classrooms because they perceived the build-in narration of film as unwanted interference with their teaching duties. It was not until the late 1950s that a modest revival of instructional film could be observed, when $8 \mathrm{~mm}$ loop films were distributed as "single concept cartridges". These could be considered the audiovisual predecessors of today's learning objects dealing with a single concept or process. Also, in those years $16 \mathrm{~mm}$ films became available against affordable prices. But at the same time the rise of television as a new medium for sounds and moving images hampered the worldwide adoption of film as an instructional medium. Film in education never lived up to its high promises.

\section{Pressey's teaching machine}

In 1924 Pressey (1926) presented his first teaching machine for drill-and-practice. It was a mechanical apparatus that offered a series a simple multiple choice questions for rehearsing simple routine tasks. Pressey's machine was based on typewriter technology with a carriage revealing a question to be answered by pressing one out of four alternative buttons. The machine could present a series of questions. By switching a lever at the back of the device the teacher could switch from multiple choice assessment mode to instructional mode requiring the right answer before displaying the next question. Long before the age of computer-assisted learning Pressey's machine already displayed many of its principles and features. The associated instructional strategy was largely based on Thorndike's connectionist model of learning (Thorndike, 1905). The model states that recurrence of a response is generally governed by its consequence in the form of reward or punishment, and that stimulusresponse associations are strengthened through repetition. As a reward mechanism Pressey's machine quite appositely released a candy after a certain number of correct answers. Its drill and practice nature reflects its 
repetitive nature. The machine appeared very effective. Therefore, similar to the case of educational film expectations were high. Pressey claimed that his machine would relief the teachers' burden by taking over timeconsuming routine tasks. He prophesised a radical change of the educational system that would greatly benefit from his new machine that achieved better and faster learning outcomes against fewer teaching efforts (Pressey, 1933). At the time during the great depression this message was not appreciated too much by the teachers, many of which had lost their jobs already and feared that this machine would makes things even worse.

\section{Instructional radio}

In the early 1900s radio stations spread all over the world. From 1910 efforts were made to use this new medium within the classrooms. The potential advantages were obvious: just like film, radio would bring the world into the classroom, making available the finest teachers and the inspiration of the greatest leaders (Cuban, 1986; Darrow, 1932). Again there were high hopes: instructional radio was ascribed great innovative potential. Nevertheless, its use in the classroom remained quite limited. First of all, a main disadvantage of radio was that content was predefined and fixed for large target groups of listeners without the opportunity to adapt it to specific needs or local differences. Practical barriers were raised by the fixed timeslots of the broadcasts that not necessarily matched the daily classroom schedules and routines. But the main problem was associated with the supposed infringements on the teachers' status and autonomous role as the leading professional and omniscient expert. Radio broadcasts were easily perceived as unwanted intruders that overtook the teaching role, compelling the real teacher to become a listener instead. As a consequence, the use of radio broadcasts in classrooms remained quite limited. Alternatively, instructional radio offered a new avenue for distance education which in those days was largely based on written correspondence via postal services. Radio broadcasts could provide realtime lectures at people's homes. But over the years instructional radio failed to attract large audiences.

\section{Instructional television}

In 1928 the first television sets became available. But large scale market adoption of television didn't occur until the 1950s. Very similar to radio and film the expectations for instructional television were high: television, as a new mass medium was imputed a bright future. The combined power of words and pictures featuring outdoor scenes, important phenomena and inspiring people created great new opportunities for teaching. Compared with film, the distribution of content was much easier because of wireless transmission. New research was undertaken about how instructional television affected classroom learning. It also raised a broader interest in understanding and generating theory on how these new media could support instruction and learning (Reiser, 1987). Although quite some investments were made to establish instructional television channels offering high quality learning content, these had only very little impact on formal education. Paradoxically, the wide and successful adoption of television as a commodity conflicted with the instructional role it was supposed to play in education, because more and more television was associated with superficial entertainment. Also, technical and organisational inconveniences hampered its wide adoption in the classroom. Regarding the small screens at the time and the poor sound quality it wasn't easy to successfully arrange instructional television sessions in a classroom with 50 or more pupils.

So, once again teachers exerted their resistance to a new technology entering their classrooms. But at a more principle level it was very difficult to meet the various conditions for student learning while using a fixed television format (Reiser, 1987). The very idea of broadcasting implied a one-to-many, one-way communication model addressing a wide audience with general purpose content. Hence, television was assumed to trigger receptive viewer modes rather than active learning modes. In one of his studies Childs (in: Almenda, 1988) found no positive contributions of using television in classrooms. The 1967 Carnegie Commission on Higher Education concluded that "the role played in formal education by instructional television has been on the whole a small one" (Reiser, 1987). Nevertheless, from the 1960s the need for alternative approaches to higher education, supporting a vision of open access en independent learning lead to the launch of distance education universities all over the world. Britain's Open University played a leading role in establishing new and innovative delivery models which included instructional television. But doubts remained: television was used for illustration and enrichment, but it seldom became the core carrier of learning contents. 


\section{Programmed instruction}

In the 1950s the influx of pupils in primary and secondary schools skyrocketed as a result of the post-war baby boom. In those days teachers were overloaded, which raised many questions about maintaining the quality of education. At the same time Russia launched its first Sputnik satellite, thus suggesting the technological and scientific superiority of communism. The resulting panic in the western world created a great incentive for the education sector to improve and innovate its methods and tools. Education was suddenly considered of strategic importance and became top priority. At the time Skinner (1958) introduced his programmed learning theory that suggested on small-step approach of reinforcement learning. Based on these ideas various technical devices (teaching machines) became available that claimed faster and better learning. In contrast with Pressey's teaching machine that was based on answering multiple choice questions, Skinner's machine required the students to enter their own responses and compare these with pre-composed answers. Skinner claimed that his approach was superior since it was based on recall rather than recognition. The machines appeared to be quite effective and unlike the case of previous innovations schools and teachers started to adopt these machines at high pace (Benjamin, 1988). But all of a sudden the advance of the machine halted. This time the parents strongly opposed against the approach: they feared the adverse effects of the mechanical teacher that lacked the human passion, enthusiasm and open mind of a real teacher. Only two decades after the era of Hitler and Stalin they suspected indoctrination by the authorities: they didn't want their children to be "programmed" by robots (Mirande, 2006). This revolt of the parents marked the end of a promising educational innovation.

\section{Audio compact cassette}

The audio compact cassette has been one of the very few successful educational media. In the late 1960s it became available as a portable alternative for the vinyl gramophone record. Greatly supported by the music industry a world-wide technical standard was adopted, which helped accomplishing a very high market penetration of audio recording equipment: almost everyone used audio cassettes. Its educational use started in distance education. The audio cassettes were mainly used as a lead-in medium for providing guidance through the written course materials (Laaser, 1986). It made a perfect match with the required flexibility because individual students could use it anytime. It was used for teaching scientific concepts, guiding experiments, analysis of source material, and counselling of students. So-called audio books were known already from the 1930 s as a means of government communication for blind people, but the audiocassette greatly extended this idea in distance education, where it also served the motivation of distance learners by establishing a more personal and intense emotional relationship between the teacher or speaker and the student (Laaser, 1986). School teachers more or less neglected the new opportunities except in the case of foreign language teaching, where audio cassettes obtained a manifest position for the training of practical speech and listening skills. Because of its good sound quality and flexibility the audio cassette persisted quite some time in car radio systems and cassette walkmans, until in the 1990s it was gradually replaced by audio compact disk and MP3 downloads.

\section{Video cassette}

Very similar to the cases of instructional film and instructional television, video cassettes were envisioned as the next moving image revolution for education. Indeed they could extend the printed learning materials with sounds and moving images so that the outside world could be represented in a more direct way. Video recorders also allowed for capturing relevant television programmes which could be viewed later on without the restrictions of broadcasting schemes. But still some barriers remained. Video production was much more expensive than producing audio. There was a general lack of appropriate content that was affordable for teachers and that matched the specific requirements of individual teachers (and learners). The main problem was technical in kind though. In contrast with audio compact cassettes there was no agreement on a common technical standard for video cassettes. Instead, the domestic market was confronted with three different technical systems that were fully incompatible: JVC's VHS-system, Philips' V2000 system and Sony's Betamax system. By the time that the winner (which was VHS) became apparent, the interest in classroom video was fading already, while new media became available like the microcomputer, multimedia CD-ROM, DVD-Video and streaming video. The video cassette never redeemed its promise. 


\section{The microcomputer}

In the 1980s education once again was confronted with a new technology that raised high expectations: the microcomputer. In contrast with audio or video programmes the microcomputer allowed for interactive programmes that smartly took into account the learners' inputs. Papert (1980) suggested that the interaction with the computer would offer the ideal environment for knowledge construction through experimentation. Shank and Cleary (1995) claimed that the computer would return all the things that were absent in schools but that are essential for any learning to take place: creative excitement, eagerness, curiosity, exploration, natural learning, fun. At the time a new branch of educational technology emerged: computer-assisted learning or computer-aided learning (CAL). It brought forth a whole new range of instructional tutorials, drill and practice exercises, and simulations for training purposes that could be used by learners independently. However, major barriers frustrated this new revolution. First of all, microcomputers were expensive. Schools simply couldn't afford to buy many of them, which resulted in low computer-to-pupil ratios. Secondly, because of rapid obsolescence microcomputers required frequent replacement. In practice many schools used outdated computers that couldn't compare with the computers that pupils used at home. Third, there was the lack of appropriate courseware that matched the teachers' preferences. Fourth, school staff lacked the technical knowhow for solving minor software or hardware problems, leaving many computers unused. Fifth, the microcomputer, which had the potential of supporting the development of individual talents through differentiated content offers was actually used for the opposite: remedial training in order to reduce deficiencies and to level out performance differences of pupils. The final problem was that the microcomputer only played a local, instrumental role at the micro-level without challenging the educational system as a whole. A renewed interest in the microcomputer as an educational means arose not until the end of the $20^{\text {th }}$ century by the advent of the internet.

\section{The general pattern of failing learning media}

The list of failing innovations could have been extended with more examples like the laser videodisc, the PLATO system (Bitzer et al., 1961) or intelligent tutoring systems. Cuban (1986) notices that the cases display a general pattern. First, new media technologies go with great expectations and enthusiasm about the new avenues for educational innovation. Then, research fails to establish any appreciable differences between traditional classroom teaching and learning with new technologies. Gradually, it becomes clear that the technologies go along with some practical inconveniences and complications that hinder teaching rather than support it. Sometimes the learners or their parents express their objections. After a while it turns out that application of the new technology in educational practice remains quite limited. In the end everything remains unchanged, while the opponents (mostly teachers) and supporters (innovators and governing bodies who made the investments) end up in mutual accusations. The next sections will elaborate three main factors that are related with this pattern of failure: educational practice, educational research, and the educational technologies used.

\section{Educational practice}

Today's school system dates from the $19^{\text {th }}$ century, meant to prepare workers for factory jobs during the industrial revolution. School was conceived as an industry itself, dedicated to the conversion of ignorant learners into qualified workers that could demonstrate agreed standards of knowledge and skills. Cuban (2001) discusses a series of mid-1980s studies about the use of computers for instruction at Stanford University. For instance, a survey among 125 Stanford professors showed that $80 \%$ used computers to prepare lectures, handouts and exams, but only 13 professors (10\%) had actually integrated the computer into their classroom practices. The pattern seems to be quite unchanging over the years. Various authors (Bates, 1995; Clarck and Estes, 1998) criticise the conservative culture in educational practice that would be rooted too much in the intuitive and traditional methods of the pre-medieval apprenticeship model, featuring an omniscient master and a naive pupil. Bates (1995) blames the fixated organisational model of classroom teaching and passes a scathing judgement on the role of teachers. According to Bates, teaching as such is not professionalised. It rarely uses a design and doesn't favour required susceptibility for scientific evidence. Teaching remains largely craft-based. As a consequence, it hardly allows for any division of labour to increase the efficiency. Educational institutes fairly resemble a collection of distinct one-man shops. Because other organisational models are rarely considered, the innovation effort is just additional to regular work and readily leads to increased unit costs. This is exactly what could have been observed during the introduction of campus-wide learning management systems at the turn of the century: the teachers' workloads went up instead of going down. From an economical perspective, such schools and universities are destined to "pine away" on the market of educational service providers, because of 
poor performance, bad quality education and disproportionately high cost. Great scepticism was raised by Sarason (1993) who ascribed the education system an oppressive impact, hidden behind unseen power relationships and cultural patterns that stifle any change or progress. In his view any school reform action is bound to ignore systemic regularities and inherent obstacles, and thus it will fail.

Westera (2010) suggests that principles underlying teaching are in many respects very similar to those of farming. Farmers as well as teachers are endowed with a built-in conservatism, which results from the neverchanging cycle of sowing and harvesting as takes place year after year. Just like farming, teaching is more than a profession, it is a vocation, a passion, a way of life, a mixture of art and skill aimed at personal care and attention for maturing organisms. New technologies which might harm this vision can, of course, expect scepticism. The attitude of the devoted, humanist teacher does neither agree with the industrial vision of policymakers, managers and politicians, nor with expansion and businesses in which output and cost are dominating and in which pupils have changed into numbers. Of course, the teachers are fighting for a good cause because those who study are not plants. It is common knowledge, that behind the gigantic facades of the schools that once merged, a smallscaled craftsmanship remains hidden in which caring teachers take pity on their plots as crofters. However, it is doubtful whether it can stay this way. In the beginning, farmers did not like to trade in their shire horse for a tractor, but today's farmers, however, spend more time at their computers than at the fields inspecting the crop. From a romantic viewpoint this may seem a disgrace, but agricultural productivity and quality have reached unparalleled levels.

\section{Educational research}

In the past, educational research had a dubious reputation and probably today this is still partly the case. Reeves (2005) unambiguously states that “...educational research as a whole has been a failed enterprise”. Others (Robinson, 1998; Lagemann and Shulman, 1999) point to the immature status of educational sciences, the lack of great achievements and the gap between common educational research and educational practice. Various authors conclude that educational research has failed to live up to its promises, while referring to a long list of innovation failures (De Bie, 2002; Kaufman, 1998; Kearsley, 1998). De Bie explains that research is isolated and unrelated to practical issues: researchers write their papers only for a small group of in-crowd researchers. The renowned research institute of the Organisation for Economic Co-operation and Development (OECD) formulated similar critical conclusions: according to this institute educational research is "unconvincing" and "irrelevant for educational practice" (CERI, 2000).

Westera (2006) asserts that many educational researchers conceive technology from a $19^{\text {th }}$ century instrumentalist viewpoint, proclaiming that pedagogy is the main driver for educational innovation and neglecting the dominant role and the substantive impact of new technologies. This goes along with a technophobic attitude, which neglects any new technology that doesn't fit into existing pedagogic models. Notwithstanding the conservative nature of teaching practice, educational research is even lagging behind practice in many respects. Experienced teachers display a lot of practical and useful knowledge about how to treat pupils, when to give support, how to give support, or when to withhold support.

The call for empirical evidence, however, seems to be counterproductive. Taking up an instrumentalist perspective, Clarck (2001) denounces the lack of empirical research evidence, while questioning the productiveness of media to learning at large. Collecting empirical evidence for these intuitive practices is a fair goal of research, but the practical implication of this is that much of the research is oriented on safe verification of common sense rather than mind-broadening issues. A random, but exemplary case would be the large scale study on the learning behaviours of Lover et al. (2004). Claiming the most fine-grained observation of high stakes study behaviour ever reported, the study reports on the self-directed studying of more than 100,000 students using a Web-based tool to prepare for U.S. college admissions tests. In this large-scale (and expensive) research project it was established that the majority of students delay their learning activities until only a few days before the exam. Unfortunately, teachers as well as students will not be impressed by this research outcome, because they know already from their own experience. Although it is appropriate that well-known patterns are verified and supported by scientific evidence, such studies don't quite add new knowledge to the field: experienced teachers will disqualify such research as being gratuitous and useless.

Today's educational research seems to have a similar position as thermodynamics and aerodynamics in previous times. At the time these disciplines were useless, or even nonexistent: the steam engine was already widely used before any scientific theory could prove it would work; airplanes crossed the ocean before any scientific 
grounding was available. Likewise, education today still has a weak scientific basis, while quite some useful practical knowledge is available (Burkhardt and Schoenfeld, 2003; Kaestle, 1993).

There is no disagreement though about the question if educational research should be strengthened. But there are many controversies about the best way to achieve this. Some parties, like the Dutch Education Council (Onderwijsraad, 2008) advocate stricter evidence-based research methodologies based on randomised controlled trials. Reeves (2006), pointing at the complexity of educational practice, rejects randomised controlled trials as a solution because outcomes are often contradictory and irreproducible, leading to what he calls "pseudoscience". Shaver (1983) puts forward that in any practical educational setting the causes and effects cannot be identified unambiguously because of confounding variables. His sobering conclusion is that controlled experiments and the notion of statistical significance are useless since in practice many input variables remain uncontrolled.

Alternatively, design-based research and action research gain popularity amongst the parts of the research community. Design-based research focuses on learning in a practical context while combining generic scientific questions with the development of specific learning environments (Burkhardt and Schoenfeld, 2003). Action research assumes the involvement of educational practitioners for investigating and improving the practical context that they're working in (Lewin, 1946). This idea of linking research with practice is not a new one. It is generally accepted that the explosion of knowledge during the last centuries is the result of a successful marriage between scientific research and working practice (De Vries, 1985; Dijksterhuis, 1950). University scholars like Galileï closely cooperated with craftsmen and technicians for creating new instruments like the telescope. Casimir (1987) uses the term "science-technology spiral" to indicate the alternating and complementary role of both fields in achieving progress. Both design-based research and action research are positioned in the so-called Pasteur Quadrant (Stokes, 1997), hinting at the way Louis Pasteur combined his scientific goals (understanding of microbiological processes) with application goals (controlling the effects of microbiological processes for the benefit of products, humans and animals). In education these practical approaches have the potential of closing the gap between research and practice, and contribute to new knowledge with high ecological validity. Exactly such contextualised research approaches, however, are not without problems, because research findings in complex local contexts are difficult to generalise or to transfer to other contexts.

\section{Educational technologies}

For over a century educational innovators have proudly announced new technologies that were supposed to produce better learning at lower cost. In most cases, however, the outcomes didn't live up to the expectations. This doesn't necessarily mean that innovators should be blamed for this. For a deeper understanding of the notion of innovation, it is necessary to look beyond straightforward, opportunist and superficial reasons for innovation and investigate the intrinsic motives and premises that drive the innovation.

A main driver for innovation is human nature. Humans are essentially creative beings that continuously come up with new ways to do things better, easier or faster. The wheel, the alphabet, mathematics, .... it is essentially the ideas that make up human culture. Indeed, civilisations are determined by ideas rather than biological aspects of human life. In essence, “...civilisation is ideas and no more than ideas" (Von Mises, 1957). Richness of ideas is a unique human feature that strongly corresponds with innovative power. Therefore innovation is a phenomenon that is inextricably bound up with humankind, and probably a main evolutionary characteristic responsible for human existence.

Over the last centuries innovative efforts have produced impressive technological achievements: sophisticated medical cures, agricultural methods, new modes of transport, communication media, information technologies etc. These achievements keep fostering the optimism for prosperity, higher standards of living or, in a broader sense, better conditions of life. The cradle of the optimism goes back to the Enlightenment, an intellectual movement in the seventeenth and eighteenth century that strongly influenced the portrayal of mankind. It is the era of great scientists, philosophers and writers, like Descartes, Newton, Leibnitz, Locke, Kant, Voltaire and Diderot. They claim that man is rational and good by nature. Also Darwin should be mentioned, whose theory of evolution reflected the conflict between science and religion, while it rejected the idea of creation of life according to the Bible book of Genesis. Rather than the creationist belief that every species was created individually by God and is not subject to change or progress, Darwin claimed that life has developed in a progressive way from primitive forms to complex organisms.

The Enlightenment marked the liberation from the medieval doctrines of magic, superstition, prejudices and the fear of God by replacing it with human rationality. The fear of God made way for a scientific description and explanation of the world. Beliefs weren't anymore accepted on the authority of priests, sacred texts, or tradition, 
but only on the basis of reason. Reinforced by the idea of natural regularity and material cause the Scientific Revolution successfully proclaimed the ideology of upward development, progress and improvement of the world, encouraged by an ever-increasing knowledge, understanding and control of nature's processes. It asserts that the individual as well as humanity as a whole can progress to perfection. Being tightly linked with the starting points of modern society, innovation is a necessary condition for all economic functioning. Innovations further the creation of new products, services and production processes, which will give an economic actor an advantage over its competitors. The predominant motto is "innovate or pine away" and the concepts of growth, progress, innovation and change seem to have become self-evident within the context of our societal system (Westera, 2005).

In recent years the pace at which new technologies become available has increased rapidly. Internet, tablets, ereaders and smart phones are fast-growing markets. So far direct technology push (broken arrow in Figure 1) on the educational system remained largely without effect. Educational institutions, positioned as public utilities rather than competitive business, lacked the stimulus for displaying innovative power and could easily ignore new technological trends and resist radical changes. Today, the conditions have changed: the pressure on education is high, new technologies are flooding the markets, and learners, be it schoolchildren or adult professionals, grow up immersed in new digital communication technologies and will demand high quality, flexible, modern and tailored learning services.

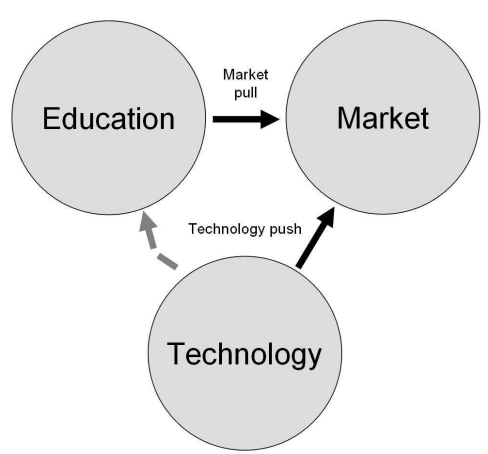

Fig.1 Technology's indirect influence on education

The associated market pull establishes a reinforced innovation driver for education, paving an indirect route for technology push. Additional pressure on educational institutes arises from competitive external providers of elearning that manage to address the market needs in a better way. The main conclusion of these developments is that despite all failures in the past education must make great efforts for its innovation.

\section{Prospects of educational media}

The domain of education is confronted with the great challenge to improve its practice of learning and teaching, to improve its research efforts and to achieve valuable innovations with new media technologies. The experience of failing innovations in the past may help avoiding new fiascos. The next sections identify a number of relevant factors that explain a favourable outlook of educational media.

\section{The internet as a societal revolution}

The emergence of the internet in the 1990s marks a fundamental change of the way society functions. The allembracing nature of the internet produced a new conceptualisation of information access, information services and social connectedness. By enabling the self-evident access to an abundance of information it promotes liberal, democratic (western) values and the independent, self-directed, responsible citizens that represent these. The allembracing nature of the internet has amplified the global economy and the exchange of cultures. The values of openness and self-directedness are more and more adopted in today's school pedagogies: by offering internet access to their pupils, schools literally raze the boundaries between the school buildings and the outside world. Also, the internet embodies the first technological innovation that enables education providers to implement changes at an institutional, organisational level. This way the microcomputer transformed from an isolated, local tool into a worldwide communication station.

The large scale adoption of new technologies 
New information and communication technologies are adopted by the market at unprecedented rates. Pioneering internet provider America Online reported 100,000 subscribers in 1992, 5,000,000 in 1995 and 10,000,000 in 1996 (The Media History Project, 2011). Worldwide the number of internet users increased from 26 Million in 1995 to 1,966 Million in 2010 (Internet World Stats, 2011). In the Netherlands, the domestic market has reached coverage of almost $100 \%$ in 2009, for the greater part involving wide-band connections (CBS, 2009). At the same time the volume of internet traffic has exploded from below 1 TeraByte per month in 2001 up to 170,000 TeraByte per month in 2009. Over the last decade, the number of people in Europe having access to wide band internet showed a steady growth each year, reaching levels up to $80 \%$ or higher. Taking also into account the growing market of smart phones it is fair to say that being connected to the internet is the default. Also schools and training institutes have adopted these new technologies as follows from the widespread connections to the internet, the increased number of school websites, and e-learning tools for content management. In the Netherlands the number of computers per students has increased; in 2009 almost any PC in primary and secundary schools has wide-band internet connection (CBS (2009). Also, 90\% of the teachers in primary schools use computers in the classroom; in secondary education this was $61 \%$ (CBS, 2009). As compared with the 1980s, the situation has completely changed: schools now consider ICT as an important means for achieving their educational goals (CBS, 2009). In accordance with the indirect technology push mechanism illustrated in figure 1, general internet services like YouTube, Hives, Facebook and MySpace set the standards for quality, speed and flexibility of services that are pursued by educational institutions.

\section{The pervasive nature of new technologies}

The new media technologies pervade our daily lives. The devices increasingly become personal devices, thus transcending the level of simple, instrumental tools. They provide ubiquitous access, they become portable or even wearable, or they are seamlessly integrated in the environment. Their use gets fully integrated in daily activities and they literally become extensions of the individual's physical and mental being. These new technologies are becoming self-evident and they will gradually transform our culture at large.

\section{Digital natives}

The digital divide between children and adults indicates that the new generation has a more positive and natural attitude towards new technologies. Today's children take these for granted as a natural condition of life. Exactly this new generation will bring forth tomorrow's teachers and researchers. Any complaints about the teachers' unlimited conservatism or the researchers' $19^{\text {th }}$ century instrumentalism and technophobia will become superfluous, since time will fade out all these problems.

\section{Natural human interfaces}

Today's user interfaces will probably be popular and hilarious gadgets in tomorrow's museums. All in all, keyboards, mice and game controllers are awkward and unpleasant devices that reinforce unnatural interactions. At the semantic level, computers hardly understand the user's intentions. These poor conditions still are severe barriers for the adoption of new technologies. New technological developments will partly remove these barriers. Already today technologies for semantic web, speech recognition, gesture recognition, body movement tracking and facial expression recognition are available that demonstrate the power of painless interaction with computer devices.

\section{More cross-disciplinary work}

Educational innovation and research are no longer the exclusive domain of pedagogues and psychologists, but will need increased support of computer scientists and graphic designers. As can be observed in various learning sciences research centres across Europe the technology-enhanced learning is indeed a multi-disciplinary domain. Exactly the balance between multiple disciplines is an important requirement and katalyst for high quality research in the domain.

\section{Maturing of the technology-enhanced learning community}


In recent years, the positioning and visibility of the technology-enhanced learning community has been strengthened substantially. The EU Commission has rated education and learning systems among the top 5 of most important societal challenges requiring ICT (European Commission, 2008). In 2009, for the first time in history, research in technology-enhanced learning received a separate funding target in a European Framework Programme. Also in 2009, a European Network of Excellence in technology-enhanced learning was established. The yearly ECTEL conference on technology-enhanced learning displays a continuous growth of participants.

\section{Web 2.0 implications}

The emergence of Web 2.0 entails a new philosophy of powers that also influences education. Web 2.0 replaces traditional content development models that are hierarchical and company driven with bottom-up models that engage individual contributors in social spaces, like Wikipedia, Blogspot and Youtube. In education this translates in open learning content and open content creation spaces like Wikiwijs (www.wikiwijs.nl) where teachers can create, adapt, share and annotate learning content in an open licensing model. Such developments have great implications for education: the relationship with educational publishing companies who used to unilaterally create and deliver the learning materials will change, as will the roles of teachers and learners.

\section{Epilogue}

Technology-enhanced learning, including educational media, will be of paramount importance for the emerging knowledge society, in which knowledge operations are much more important than any material operation. ICT will be a dominant characteristic of any professional task. The knowledge society requires a higher level of education of the population as well as a continuous updating and upgrading of its knowledge and competencies. For being successful on a global market knowledge, creativity, collaborative innovation and competitiveness will be essential. Accordingly, learning demands will increase in volume, will be more diverse and will entail easy customisation, personalisation and flexible delivery. This not only calls for increased innovation efforts, but also indicates that despite frequent failures in the past educational media have great prospects. For this practitioners, researchers and innovators should align their ambitions and jointly take the challenge. As Sarason stated "the biggest risk in education is not taking one" (Sarason, 1993).

\section{References}

Almenda, M.B. (1988). Speaking personally with Gayle Childs. American Journal of Distance Education. 2(2), 68-74.

Baldwin, N. (1995). Edison: Inventing the Century. New York: Hyperion.

Bates, A. (1995). Technology, Open Learning and Distance Education. London/New York: Routledge.

Benjamin, L.T. (1988). A history of teaching machines. American Psychologist, 43(9), 703-719.

Bitzer, D., Lichtenberger, W. and Braunfeld, P.G. (1961). PLATO: an automatic teaching device. IRE

Transactions on Education, E-4, 157-161.

Burkhardt, H. and Schoenfeld, A.H. (2003). Improving Educational Research: Toward a More Useful, More Influential, and Better-Funded Enterprise. Educational Researcher, 32(9), 3-14.

Casimir, H.B.G. (1987). Natuurwetenschap, techniek en maatschappij. In H.B.G. Casimir (Ed.), Waarneming en Visie. Over Wetenschap en Maatschappij 40-48. Meulenhoff, Amsterdam.

CBS (2009) De Digitale Economie 2009. Centraal Bureau voor de Statistiek, Heerlen/Den Haag

CERI (2000). Knowledge Management in the Learning Society. Paris: Organisation for Economic Co-operation and Development.

Clarck, R.E. and Estes, F. (1998). Technology or Craft: What are We Doing? Educational Technology, 38(5), 511. 
Clarck, R.E. (2001). Learning from Media. Arguments, Analysis and Evidence. Information Age Publishing, Greenwich.

Cuban, L (2001) Oversold and underused, Computers in the classroom, Harvard University Press. Cambridge, MA.

Cuban, L. (1986). Teachers and Machines. The classroom use of technology since 1920. New York: Teachers College Press.

Darrow, B. (1932). Radio: The Assistant Teacher. Columbus: R.G. Adams

De Bie, D. (2002). Het beperkte nut van onderwijsonderzoek. HBO-Journaal, oktober, 40-41.

De Vries, G. (1985). De ontwikkeling van wetenschap. Een inleiding in de wetenschapsfilosofie. Groningen: Wolters-Noordhoff.

Dijksterhuis, E.J. (1950). De Mechanisering van het Wereldbeeld. $6^{\text {th }}$ edition, 1989. Amsterdam: Meulenhoff. European Commission (2008). Shaping the ICT research and innovation agenda for the next decade. Report on the European Commission's Public On-line Consultation. Brussels: European Commission. Retrieved Februari 23, 2011 from http://ec.europa.eu/enterprise/newsroom/cf/itemlongdetail.cfm?item_id=2521

Internet World Stats (2011) Data retrieved Mai 4, 2011 from http://www.internetworldstats.com/stats.htm Kaestle, C. (1993). The Awful Reputation of Education Research. Educational Researcher, 22(1), $23-31$.

Kaufman, R. (1998). The Internet as the ultimate technology and panacea. Educational Technology, 38(1), 6364.

Kearsley, G. (1998). Educational Technology: A critique. Educational Technology, 38(1), 47-51.

Laaser, W. (1986). Some Didactic Aspects of Audio-Cassettes in Distance Education. Distance Education, 7(1), $143-52$.

Lagemann, E.C. and Shulman, L.S. (1999). Issues in Education Research: Problems and Possibilities. San Francisco: Jossey-Bass.

Lewin, K. (1946). Action research and minority problems. Journal of Social Issues, 2, 34-46.

Lover, E., Radlinski, F., Crespi, V.H., Millet, J. and Cushing, L. (2004). Online study behavior of 100,000 students preparing for the SAT, ACT, AND GRE. Journal of Educational Computing Research, 30(3), 255-262. Mirande, M. (2006). De onstuitbare opkomst van de leermachine. Assen: Koninklijke Van Gorcum.

Onderwijsraad (2008). Onderwijs en maatschappelijke verwachtingen. Den Haag: Onderwijsraad.

Papert, S. (1980). Mindstorms. New York: Basic Books.

Pressey, S.L. (1926). A simple apparatus which gives tests and scores and teaches. School and Society, 23(586), 373-376.

Pressey, S.L. (1933). Psychology and the New Education. New York: Harper and Bros.

Reiser, R.A. (1987). Instructional technology: A history. In R.M. Gagne (Ed.), Instructional technology. Lawrence Erlbaum Associates, Hillsdale NJ.

Reeves, T. (2005). Design-based research for advancing educational technology. In M. Valcke, K. de Cock, D. Gombeir, and R. Vanderlinde (Eds.), Meten en Onderwijskundig onderzoek. Proceedings van de 32e Onderwijs Research Dagen (pp. 33-39). Universiteit Gent, Vakgroep Onderwijskunde, Gent.

Reeves, T. (2006). Design research from a technology perspective. In J. Van den Akker, K. Gravemeijer, S. McKenney, and N. Nieveen (Eds.), Educational Design Research (pp. 52-66). Routledge, New York.

Robinson, V. (1998). Methodology and the Research-Practice Gap. Educational Researcher, 27(1), 17-26. 
Sarason, S.B. (1993). The predictable failure of educational reform: Can we change course before it's too late? San Francisco: Jossey-Bass Publishers.

Schank, R.C. and Cleary, C. (1995). Engines for Education. Hillsdale NJ: Lawrence Erlbaum Associates, Inc. Shaver, J.P (1983). The verification of independent variables in teaching methods research. Educational Researcher, 12(8), 3-9.

Skinner, B.F. (1958). Teaching machines. Science, 128(3330), 969-977.

Sleeman, D. and Brown, J. S. (1982). Intelligent Tutoring Systems. New York: Academic Press.

Stokes, D.E. (1997). Toward a New Research Paradigm. Pasteur's Quadrant: Basic Science and Technological Innovation. Washington DC: Brookings Institution Press.

Thorndike, E.L. (1905). Elements of psychology. New York: A.G. Seiler.

Von Mises, L. (1957). Theory and History, an Interpretation of Social and Economic Evolution. New Haven: Yale University Press.

Westera, W. (2005). Beyond functionality and technocracy: creating human involvement with educational technology. Educational Technology and Society, 8(1), 28-37.

Westera, W. (2010). Food for thought: What education could learn from agriculture. Educational Technology Magazine, 50(6), 37-40.

Westera, W. (2006). The E-Learning Cabaret: Do's and Don'ts in E-Learning Design, Book of Abstracts, Online Educa Berlin, 12th International Conference on Technology Supported Learning and Teaching (pp. 169-171). Berlin: ICWE-GmbH. 